\title{
ANALISIS PEMBERIAN TUNJANGAN SOSIAL (DIRECT REWARD) TERHADAP PRESTASI KERJA SELURUH KARYAWAN JAWA TIMUR PARK, MALANG
}

\author{
VIVIA MAYA RAFICA \\ Dosen STMIK ASIA MALANG
}

\begin{abstract}
ABSTRAKSI
Tujuan dari penelitian ini, adalah untuk mengetahui sejauh mana pengaruh antara pemberian tunjangan sosial dengan prestasi kerja. Serta untuk mengetahui program tunjangan sosial manakah yang paling dominan pengaruhnya terhadap peningkatan prestasi kerja karyawan.

Jenis penelitian yang digunakan adalah jenis penelitian penjelasan dengan menggunakan pengujian hipotesis. Populasi penelitian adalah seluruh karyawan Jawa Timur Park, Malang yang berjumlah 130 orang. Mengingat keterbatasan waktu dan biaya, penulis hanya mengambil dari 50\% dari populasi yaitu sebanyak 65 orang karyawan sebagai responden. Metode pengumpulan data yang digunakan adalah observasi, dokumentasi, dan kuesioner. Sedangkan metode yang digunakan untuk menguji hipotesa ini adalah metode statistik dengan menggunakan program SPSS.

Analisis data dan pengujian hipotesis menggunakan regresi berganda. Berdasarkan hasil pengujian dengan analisis korelasi berganda, telah terbukti bahwa peubah jaminantenaga kerja $\left(X_{1}\right)$, peubah pelayanan kesehatan (X2), dan peubah program bantuan karyawan $\left(X_{3}\right)$ secara bersama-sama mempunyai hubungan yang bermakna terhadap peubah prestasi kerja $(Y)$. Berdasarkan pengujian hipotesis kedua dengan analisis secara parsial, menyatakan bahwa peubah jaminan tenaga kerja $\left(X_{1}\right)$ berpengaruh paling dominan terhadap peubah prestasi kerja (Y) terbukti kebenarannya.
\end{abstract}

\section{PENDAHULUAN}

Perkembangan industri pariwisata saat ini tumbuh sangat pesat, sehingga menimbulkan persaingan yang sangat ketat. Salah satunya mereka berlomba, menawarkan berbagai fasilitas, kualitas pelayanan, hiburan, dan peyajian sebaik mungkin untuk memberikan nilai tambah pada pelayanan yang ditawarkannya. Upaya tersebut dilakukan agar bertahan di tengah persaingan yang sangat ketat dan tetap menjadi pilihan utama bagi wisatawan.

Malang merupakan salah satu daerah di Indonesia yang banyak dikunjungi oleh para wisatawan, baik wisatawan luar negeri maupun wisatawan domestik. Jawa Timur Park, Malang merupakan salah satu industri atau perusahaan yang bergerak di bidang pariwisata, yang berarti sebagai organisasi dalam suatu sistem, yaitu rangkaian dan hubungan antar bagian komponen yang bekerja sama sebagai keseluruhan. Tunjangan sosial sangat penting bagi karyawannya, karena tunjangan sosial merupakan suatu bentuk perhatian dari pihak perusahaan terhadap karyawannya. Dan pemberian tunjangan sosial dari perusahaan tersebut dapat berpengaruh terhadap prestasi kerja karyawan. Apabila tunjangan sosial diberikan secara tepat dan benar, para karyawan akan lebih berprestasi untuk mencapai tujuantujuan organisasi.

\section{TINJAUAN PUSTAKA}

Definisi dan Peranan Tenaga Kerja

Tenaga kerja manusia merupakan salah satu faktor produksi yang digunakan dalam perusahaan. Tenaga kerja adalah faktor produksi yang hidup, dinamis, dan sekaligus merupakan kesatuan ekonomis, psikologis, dan sosial. Hal ini berarti bahwa tenaga kerja tersebut memiliki keinginan, emosi, rasio atau akal, dan lingkungan. Dengan demikian sudah sepantasnya perhatian perusahaan lebih banyak ditujukan kepada masalah tenaga kerja, seperti mutu tenaga kerja dan pengawasan tenaga kerja. Pengertian Reward (Kompensasi, Insentif)

Reward merupakan imbalan bagi jasa, tenaga, pikiran, dan waktu yang 4diberikan oleh karyawan. Kompensasi merupakan faktor yang penting dan kompleks bagi manajemen personalia (Silabus Forum.search.ekonomiperusahaan: 2003.html). Hal ini disebabkan dipihak perusahaan dituntut adanya kompensasi yang berdasarkan logika dan rasio.

\section{Pengertian Tunjangan Sosial}

Menurut Hasibuan tunjangan sosial adalah, "Balas jasa tambahan (financial atau non finansial) yang diberikan berdasarkan kebijakan perusahaan terhadap semua pegawai dalam usaha untuk meningkatkan kesejahteraan mereka, misalnya tunjangan hari raya, uang pensiun, pakain dinas, rekreasi, kesehatan, dan lain-lain". (Hasibuan, 2005:118).

\section{Bentuk- Bentuk Tunjangan Sosial}

Kertonegoro (2001:20-21), menyebutkan beberapa bentuk program tunjangan sosial yang umum diberikan kepada karyawan pada sebuah perusahaan sebagai berikut:

1. Program Tunjangan Sosial

2. Program Tunjangan Kecelakaan Kerja 
3. Program Tunjangan Hari Tua, Cacat dan Kematian

4. Program Tunjangan Pengangguran yang Tidak Dikehendaki

5. Program Tunjangan Asuransi Sosial Tenaga Kerja

\section{Pengertian Prestasi Kerja}

Prestasi kerja karyawan merupakan salah satu hal yang sangat diharapkan oleh perusahaan dalam rangka mencapai tujuantujuan yang telah ditetapkan, baik tujuan jangka pendek maupun jangka panjang. Prestasi kerja karyawan dapat diartikan sebagai kemampuan karyawan dalam melaksanakan tugas yang dibebankan kepadanya.

\section{Definisi Penilaian Prestasi Kerja}

Menurut Henry Simamora Panggabean penilaian prestasi kerja merupakan, "Proses yang dilakukan organisasi untuk mengevaluasikan pelaksanaan kerja individu karyawan pada organisasi selama periode waktu tertentu". (Henry Simamora, 2001:415).

\section{Tujuan Penilaian Prestasi Kerja}

Terdapat beberapa tujuan penting dalam penilaian prestasi kerja karyawan yang tidak dapat dicapai oleh metode lain. Tujuan pokok dari sistem penilaian prestasi kerja adalah menghasilkan informasi yang akurat dan valid berkenaan dengan perilaku dan prestasi kerja anggota organisasi atau perusahaan.

an-tujuan khusus tersebut secara mendasar dapat dibagi manjadi 2 bagian yaitu:

1. Tujuan Evaluasi

2. Tujuan Pengembangan

\section{Cara Penilaian Prestasi Kerja}

Menurut Dharma sehubungan dengan penilaian prestasi kerja adalah, "Banyak cara pengukuran yang dapat digunakan seperti penghematan, kesalahan, dan sebagainya". (Dharma, 2002:55).

Penilaian prestasi kerja sangat penting bagi suatu organisasi. Dengan penilaian prestasi kerja tersebut suatu organisasi dapat melihat sampai sejauh mana faktor manusia dapat menunjang tujuan suatu organisasi. Penilaian prestasi kerja dapat memotivasi karyawan agar terdorong untuk bekerja lebih baik. Oleh karena itu diperlukan penilaian prestasi yang tepat dan konsisten.

\section{Tahapan dan Elemen Pokok Sistem} Penilaian Prestasi Kerja

Tahapan dan Elemen Pokok Sistem Penilaian Prestasi Kerja meliputi:

1. Identifikasi

2. Observasi

3. Pengukuran

4. Pengembangan

Adapun elemen-elemen pokok sistem penilaian mencakup kriteria-kriteria yang ada hubungannya dengan pelaksanaan kerja, ukuran-ukuran kriteria tersebut, dan pemberian umpan balik kepada karyawan seperti ditunjukkan pada gambar berikut. (Handoko, 2001:138)

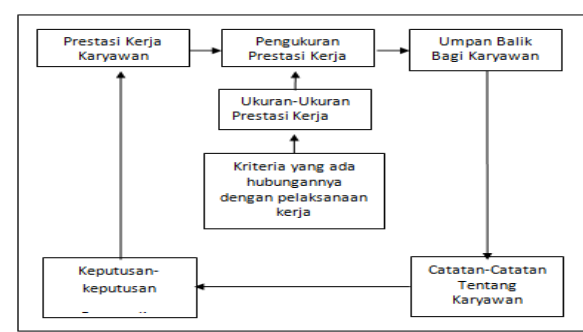

Prestasi kerja sebagai hasil kerja (output) yang berasal dari adanya perilaku kerja serta lingkungan kerja tertentu yang kondus if.

Hubungan Antara Jaminan Sosial dan Prestasi Kerja

Menurut Handoko (2001:134), faktor yang mempengaruhi prestasi kerja adalah kompleks. Hampir semua aspek ekonomis, teknis, dan perilaku mempunyai pengaruh terhadap tingkat prestasi kerja karyawan, ada banyak faktor yang mempengaruhi prestasi kerja karyawan. Karyawan bekerja dengan produktif atau tidak tergantung pada motivasi, kepuasan kerja, tingkat stres, kondisi fisik pekerja, dan aspekaspek ekonomis, teknis serta perilaku lainnya. Pemahaman terhadap faktor-faktor yang mempengaruhi terhadap prestasi ini sangat penting, karenanya fungsi personalia kemudian dapat memilih faktor-faktor peningkatan prestasi yang sesuai dengan situasi tertentu.

Dari beberapa teori yang telah diuraikan di atas, model teorinya adalah sebagai berikut:

\section{Model Teori}

Gambar 1. Model Teori Hubungan Jaminan Sosial Terhadap Prestasi Kerja

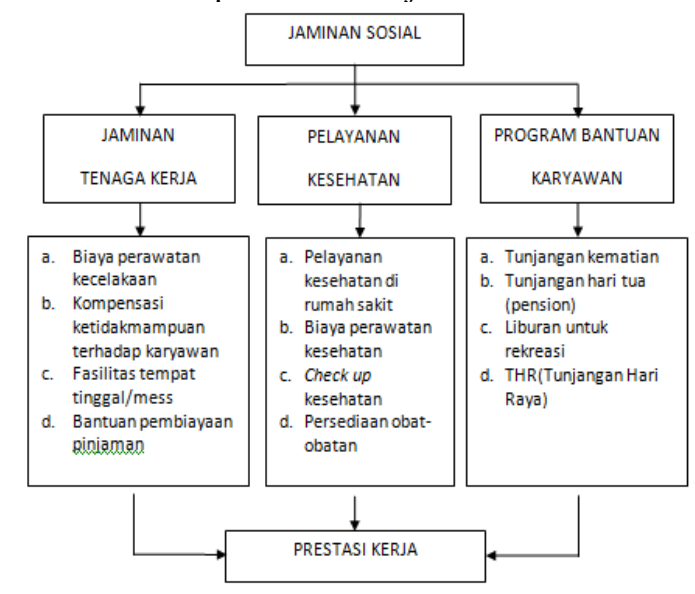

Keterangan:

Tunjangan sosial merupakan pemberian berupa uang, barang atau jasa di luar yang diterima karyawan yang terdiri dari jaminan tenaga kerja, pelayanan kesehatan dan program bantuan karyawan. 
Adanya jaminan sosial dari perusahaan, diharapkan akan berpengaruh pada prestasi kerja karyawan sebagaimana yang dihadapi oleh perusahaan tersebut.

Melihat model teori di atas dapat disusun suatu model konsep seperti di bawah ini:

Gambar 2 Model Konseptual

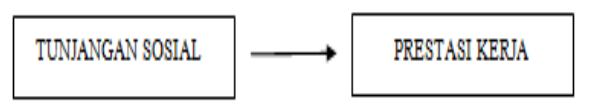

Hipotesis

Hipotesis dikatakan sebagai jawaban sementara, karena jawaban yang diberikan baru didasarkan pada teori yang relevan belum didasarkan pada fakta-fakta empiris yang diperoleh melalui pengumpulan data.

Dari pernyataan di atas dan berdasarkan model teori dan model konsep yang ada, maka model hipotesis yang ada di dalam penelitian ini dapat digambarkan sebagai berikut: Gambar 3 Model Hipotesis

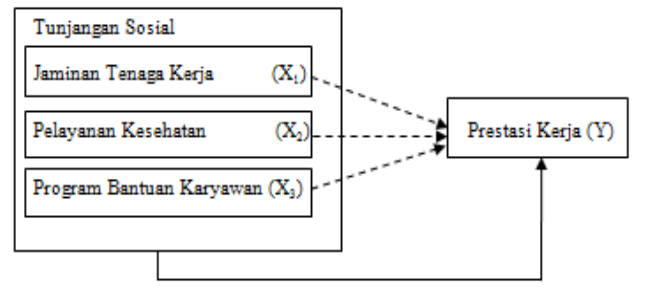

Keterangan :

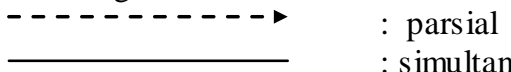

Berdasarkan model hipotesis tersebut, maka dapat dirumuskan hipotesis sebagai berikut:

a. Diduga bahwa tunjangan sosial yakni: jaminan tenaga kerja $\left(\mathrm{X}_{1}\right)$ secara parsial mempunyai pengaruh yang bermakna terhadap prestasi kerja karyawan (Y).

b. Diduga bahwa tunjangan sosial yakni: pelayanan kesehatan $\left(\mathrm{X}_{2}\right)$ secara parsial mempunyai pengaruh yang bermakna terhadap prestasi kerja karyawan (Y).

c. Diduga bahwa tunjangan sosial yakni: program bantuan karyawan $\left(\mathrm{X}_{3}\right)$ secara parsial mempunyai pengaruh yang bermakna terhadap prestasi kerja karyawan (Y).

d. Diduga bahwa tunjangan sosial yakni: jaminan tenaga kerja (X1), pelayanan kesehatan (X2), dan program bantuan karyawan (X3) secara simultan mempunyai pengaruh yang bermakna terhadap prestasi kerja karyawan (Y).

\section{METODE PENELITIAN}

\section{Jenis Penelitian}

Metode yang digunakan dalam penelitian ini adalah survey explanatory. Menurut Ker Linger yang dikutip oleh Sugiyono (2002:7), "Metode survey yaitu metode penelitian yang dilakukan pada populasi besar maupun kecil, tetapi data yang dipelajari adalah data dari sample yang diambil dari populasi tersebut, sehingga ditemukan gambaran dan hubungan antar variabel".

Penelitian ini dilakukan dengan maksud untuk menguji dan menganalisis adanya pengaruh dan hubungan antara pemberian jaminan sosial (direct reward) terhadap prestasi kerja seluruh karyawan Jawa Timur Park, Malang.

\section{Peubah dan Pengukuran}

Berdasarkan kajian konsep dan teori yang sesuai dengan masalah di atas, maka dapat ditentukan peubah-peubah sebagai berikut:

1. Peubah Bebas (Independent Variable)a. Jaminan Tenaga Kerja, $b$. Pelayanan Kesehatan, $c$. Program Bantuan Karyawan

2. Peubah Terikat (Dependent Variable)

Dari peubah prestasi kerja ini, dapat ditentukan item-item sebagai berikut:a. Tepat waktu, b. Tangkas dan cakap, c. Teliti, d. Output (Hasil)

3. Pengukuran

Langkah selanjutnya adalah mengadakan pengukuran atas peubah-peubah tersebut, adapun pengukuran yang digunakan untuk mengukur tanggapan responden adalah skala likert.

\section{Populasi dan Sampel}

Mengingat keterbatasan waktu dan biaya, maka peneliti hanya mengambil 50\% dari populasi, yaitu sebanyak 65 orang karyawan. Hal ini sesuai dengan pendapat Suharsimi Arikunto bahwa, "Apabila subyek kurang dari 100, lebih baik diambil semua sehingga penelitiannya merupakan penelitian populasi. Selanjutnya jika jumlah subyeknya besar dapat diambil antara 10\% - 15\% atau 20\% - 25\% atau lebih". (Arikunto, 2002:112).

\section{Metode Pengumpulan Data}

Metode pengumpulan data yang digunakan dalam penyusunan skripsi ini, diuraikan sebagai berikut:
a. Observasi
b. Dokumentasi
c. Kuisioner

\section{Metode Analisis}

Teknik yang digunakan untuk menguji hubungan dan pengaruh peubah bebas terhadap peubah tergantung dan dugaan tentang penganuh tersebut, maka digunakan analisis data yang bertujuan untuk menguji kebenaran hipotesis.

a. Untuk mendeskripsikan prestasi kerja karyawan digunakan analisis deskriptif, yaitu dengan menginterprestasikan komponen jaminan sosial, yakni jaminan 
tenaga kerja, pelayanan kesehatan, dan program bantuan karyawan.

b. Dalam penelitian ini, analisis yang digunakan adalah analisis regresi berganda dengan persamaan regresi sebagai berikut:

$\mathrm{Y}=\beta \mathrm{o}+\beta 1 \mathrm{x} 1+\beta 2 \times 2+\beta 3 \times 3+\mathrm{e}$

Dimana:

$\mathrm{Y} \quad$ : prestasi kerja

$\mathrm{X} 1$ : jaminan tenaga kerja

X2 : pelayanan kesehatan

X3 : program bantuan kerja

Bo : konstanta

$\beta 1 . . \beta 3 \quad$ : koefisien regresi

e : kesalahan pengganggu

Metode analisis yang digunakan untuk menguji hipotesis adalah metode statistik, dimana tahapan-tahapan analisis penelitian menggunakan paket SPSS for windows 10 program dan dapat dihitung dengan manual dengan menggunakan rumus-rumus statistik.

\section{Teknik Sampling}

Teknik sampling adalah merupakan teknik pengambilan sampel. Untuk menentukan sampel yang akan digunakan dalam penelitian, terdapat berbagai teknik sampling yang digunakan dalam penelitian ini adalah Simple Random Sampling.

\section{PEMBAHASAN HASIL PENELITIAN Gambaran Umum Jawa Timur Park, Malang \\ PT. Bunga Wangsa Sedjati dengan} dukungan sekolah, perguruan tinggi, seniman, pengrajin, dan pelaku bisnis di Jawa Timur dan atas persetujuan Walikota Batu mendirikan Jawa Timur Park yang mulai beroperasi sejak tanggal 9 Desember 2001 untuk ikut serta dalam mempromosikan Jawa Timur sebagai daerah tujuan wisata.

Jawa Timur Park merupakan obyek wisata dengan konsep dasar yang memadukan secara serasi pendidikan dan pariwisata dimana pengunjung bisa bermain dan belajar sekaligus di satu tempat dan waktu.

\section{Diskripsi Responden}

Di dalam bagian ini diuraikan gambaran responden, baik mengenai tingkat usia responden, jenis kelamin responden, tingkat pendidikan formal responden, dan status responden di Jawa Timur Park, Malang.

Penelitian dilakukan dengan cara menyebarkan kuesioner kepada 65 responden. Kuesioner diberikan kepada karyawan dan dikumpulkan pada saat telah menyelesaikan tugas/kerja.

\section{Diskripsi Peubah}

Hasil dari penelitian yang telah dilakukan pada karyawan Jawa Timur Park antara peubah jaminan sosial terhadap peubah prestasi kerja, secara keseluruhan yaitu : a. Peubah Jaminan Tenaga Kerja $\left(\mathrm{X}_{1}\right)$

b. Peubah Pelayanan Kesehatan $\left(\mathrm{X}_{2}\right)$

c. Program Bantuan Karyawan $\left(\mathrm{X}_{3}\right)$

d. Peubah Prestasi Kerja (Y)

Hasil Validitas Dan Reliabilitas

Uji validitas dan reliabilitas di sini menggunakan metode alpha cronbach perhitungannya dengan bantuan komputer SPSS 10 for windows program. Rekapitulasi hasil analisis item-total statistics untuk indikatorindikator dari peubah-peubah jaminan tenaga kerja $\left(\mathrm{X}_{1}\right)$, peubah pelayanan kesehatan $\left(\mathrm{X}_{2}\right)$, peubah program bantuan karyawan $\left(\mathrm{X}_{3}\right)$, dan peubah prestasi kerja (Y)

\section{Uji Asumsi Klasik Regresi}

a. Uji Normalitas

b. Uji Linieritas

Pengujian Hipotesis Dan Interprestasi

Untuk menguji hipotesis akan digunakan pengujian hipotesis-hipotesis yang telah diajukan adalah sebagai berikut:

a. Uji Hipotesis I

Secara keseluruhan hasil uji F seperti tercantum pada tabel 10 berikut ini. Tabel 1. Rekapitulasi Hasil Hasil Uji F Antara Peubah Bebas Dengan Peubah Terikat

\begin{tabular}{|l|l|l|l|l|l|}
\hline $\begin{array}{l}\text { Peubah } \\
\text { terikat }\end{array}$ & $\begin{array}{l}\text { Peubah } \\
\text { bebas }\end{array}$ & $\begin{array}{l}\text { Koefisien } \\
\text { korelasi } \\
(\mathrm{R})\end{array}$ & $\begin{array}{l}\text { Koefisien } \\
\text { determinasi } \\
(\mathrm{R} 2)\end{array}$ & $\begin{array}{l}\mathrm{F} \\
\text { hitung }\end{array}$ & $\begin{array}{l}\mathrm{F} \\
\text { Tabel }\end{array}$ \\
\hline $\mathrm{Y}$ & $\mathrm{X} 1, \mathrm{X} 2, \mathrm{X} 3$ & 0,798 & 0,637 & 35,614 & 2,76 \\
\hline
\end{tabular}

Sumber : Data SPSS for windows 10.00 (pada bulan Desember 2016)

Keterangan:

$\mathrm{X}_{1}=$ Peubah jaminan tenaga kerja

$\mathrm{X}_{2}=$ Peubah pelayanan kesehatan

$\mathrm{X}_{3}=$ Peubah program bantuan karyawan

$\mathrm{Y}=$ Peubah prestasi kerja

b. Uji hipotesis II

Secara keseluruhan hasil uji t seperti tercantum pada tabel 11 berikut ini.

Tabel 2.Rekapitulasi Hasil Uji i Antara Peubah Bebas Dengan Peubah Terikat

\begin{tabular}{|l|l|l|l|l|l|}
\hline $\begin{array}{l}\text { Peubah } \\
\text { Terikat } \\
\text { Y }\end{array}$ & $\begin{array}{l}\text { Peubah } \\
\text { bebas }\end{array}$ & $\begin{array}{l}\text { Korelasi } \\
\text { parsial } \\
(\mathrm{r})\end{array}$ & $\begin{array}{l}\text { Koefisien } \\
\text { regresi } \\
(\mathrm{b})\end{array}$ & thitung & $\begin{array}{l}\mathrm{t} \\
\text { tabel }\end{array}$ \\
\cline { 2 - 6 } & $\mathrm{X} 1$ & 0,576 & 0,314 & 5,503 & 1,669 \\
\cline { 2 - 6 } & $\mathrm{X} 2$ & 0,518 & 0,209 & 4,735 & 1,669 \\
\cline { 2 - 6 } & $\mathrm{X} 3$ & 0,396 & 0,179 & 3,364 & 1,669 \\
\hline \multicolumn{5}{|c|}{ Konstanta: 3,884} \\
\hline R Square: 0,637 \\
Adj. R Square: 0,619
\end{tabular}

Sumber : Data SPSS for windows 10.00 (pada bulan Desember 2016)

\section{Interpretasi Hasil Penelitian}

Berdasarkan penelitian yang dilakukan di atas, maka dapat diinterpretasikan sebagai berikut: 
1) Jaminan tenaga kerja

Berdasarkan analisis korelasi berganda dapat diketahui bahwa peubah jaminan tenaga kerja (X1) mempunyai hubungan yang signifikan dengan peubah prestasi kerja (Y). Dari hasil korelasi parsial tersebut menunjukkan bahwa peubah jaminan tenaga (X1) kerja memberikan pengaruh yang paling besar terhadap prestasi kerja (Y) bila dibandingkan dengan peubah-peubah lainnya. Hal ini dibuktikan dengan nilai koefisien regresi sebesar 0,314 dan koefisien regresi parsial sebesar 0,576, yakni paling besar diantara peubah yang ada. Jadi peubah jaminan tenaga kerja (X1) memiliki hubungan dominan terhadap peubah prestasi kerja (Y) dibandingkan peubah lainnya, karena karyawan lebih termotivasi dalam bekerja/berprestasi, apabila karyawan di dalam bekerja hidupnya terjamin/dijamin oleh perusahaan.

2) Pelayanan kesehatan

Dari analisis parsial diperoleh nilai korelasi parsial sebesar 0,518 atau 51,8\%. Jadi peubah pelayanan kesehatan (X2) memiliki hubungan dominan setelah peubah jaminan tenaga kerja (X1) terhadap peubah prestasi kerja (Y).

3) Program bantuan karyawan

Dari analisis parsial diperoleh nilai korelasi parsial sebesar 0,396 atau 39,6\% memberikan pengaruh terhadap prestasi kerja. Jadi peubah program bantuan karyawan (X3) memiliki hubungan paling rendah terhadap peubah prestasi kerja (Y) dibandingkan peubah lainnya.

4) Prestasi kerja

Dari analisis di atas dapat terlihat ada hubungan yang bermakna (signifikan) yang dihubungkan secara bersama-sama antara peubah bebas dengan peubah terikat, karena nilai koefisien regresi X1, X2 dan X3 semuanya positif, yaitu secara berturut-turut (0,314), (0,209), dan $(0,179)$ dan dengan nilai multiple $\mathrm{R}=0,798$. Hal ini berarti dalam usaha untuk meningkatkan prestasi kerja faktor-faktor yang mempengaruhinya tidak dapat berdiri sendiri tetapi saling mempengaruhi.

Sementara itu hasil analisis korelasi parsial dapat diketahui bahwa peubah jaminan tenaga kerja (X1) mempunyai hubungan prestasi kerja (Y) terhadap peubah terikat, yaitu sebesar 0,576. Sedangkan hasil analisis regresi berganda peubah bebas jaminan tenaga kerja (X1) paling besar pengaruhnya terhadap peubah terikat prestasi kerja (Y) yaitu sebesar 0,314. Jadi dengan demikian hipotesis kedua yang menduga bahwa peubah yang paling dominan mempengaruhi prestasi kerja (Y) dapat dibuktikan.

\section{KESIMPULAN DAN SARAN-SARAN Kesimpulan}

1. Dari teori yang ada terdapat dua konsep yaitu konsep jaminan sosial dan konsep prestasi kerja. Konsep jaminan sosial terdiri dari jaminan tenaga kerja, pelayanan kesehatan, dan program bantuan karyawan.

2. Berdasarkan hasil pengujian pertama bahwa tunjangan sosial yakni: jaminan tenaga kerja $\left(\mathrm{X}_{1}\right)$ secara parsial mempunyai pengaruh yang bermakna terhadap prestasi kerja karyawan (Y).Terbukti dari nilai koefisien regresi sebesar 0,314 dan koefisien regresi parsial sebesar 0,576.

3. Berdasarkan hasil pengujian kedua bahwa pelayanan kesehatan $\left(\mathrm{X}_{2}\right)$ secara parsial mempunyai pengaruh yang bermakna terhadap prestasi kerja karyawan (Y).Terbukti dari nilai koefisien regresi sebesar 0,209 dan koefisien regresi parsial sebesar 0,518.

4. Berdasarkan hasil pengujian ketiga Diduga bahwa tunjangan sosial yakni: program bantuan karyawan $\left(\mathrm{X}_{3}\right)$ secara parsial mempunyai pengaruh yang bermakna terhadap prestasi kerja karyawan (Y) Terbukti dari nilai koefisien regresi sebesar 0,396 dan koefisien regresi parsial sebesar 0,179 .

5. Berdasarkan hasil pengujian keempat bahwa jaminan tenaga kerja, pelayanan kesehatan, dan program bantuan karyawan secara bersama-sama mempunyai pengaruh yang bermakna terhadap prestasi kerja, dimana dengan telah dipenuhi semua hal di atas, maka mampu menunjukkan prestasi kerja yang diharapkan. Terbukti dari koefisien korelasi berganda, yaitu (Multiple R) 0,798 dengan uji F hitung sebesar 35,614 > F tabel sebesar 2,76.

\section{Saran-Saran}

Berdasarkan hasil penelitian maka saran yang dapat diberikan pada Jawa Timur Park, Malang adalah sebagai berikut:

a. Secara umum hendaknya program jaminan sosial yang telah ada di Jawa Timur Park, Malang perlu ditingkatkan lagi, antara lain:

1) Untuk meningkatkan prestasi kerja karyawan, sebaiknya pihak perusahaan memberikan rasa aman serta kenyamanan bagi para karyawannya. Hal ini dapat diwujudkan dengan cara melindungi serta memperhatikan karyawan dalam bentuk memasukkan para karyawan dalam jaminan tenaga kerja, misalnya reward (kompensasi dan insentif) atau indirect reward (outbound dan cuti). 
2) Pihak perusahaan hendaknya merumuskan program kerja yang khusus menangani kesehatan karyawan dan memasukkan dalam rencana induk perusahaan. Jadi dalam menangani masalah kesehatan tidak hanya cukup dengan mengikutsertakan karyawan pada keanggotaan ASTEK, tetapi juga harus memperhatikan hal-hal lain sebagai berikut, misalnya:

- Kebutuhan dan keinginan karyawan

- Jenjang karir karyawan

- Kesejahteraan karyawan

3) Akan lebih baik apabila perusahaan menyisihkan dana atau keuntungan yang diperoleh perusahaan untuk kepentingan karyawannya dalam bentuk indirect reward paling tidak satu tahun sekali yang diperuntukkan bagi karyawan dan keluarganya. Hal ini bertujuan demi kebaikan perusahaan juga untuk menciptakan hubungan yang baik antara karyawan dengan atasan, sehingga tercipta suasana yang harmonis di dalam perusahaan.

4) Agar prestasi kerja mengalami peningkatan, maka hendaknya pihak perusahaan memperhatikan peubah jaminan tenaga kerja yang merupakan peubah yang paling dominan mempengaruhi prestasi kerja.

5) Sebaiknya pelayanan kesehatan yang diberikan kepada karyawan bukan sematamata sebagai jaminan kesehatan, akan tetapi diharapkan sebagai motivasi bagi karyawan untuk meningkatkan prestasi kerja.

6) Bagi peneliti lain, sebaiknya lebih memperluas lagi dengan mungkin mengambil peubah-peubah yang baru, atau obyek penelitian baru, sehingga hasil penelitiannya lebih akurat

\section{DAFTAR PUSTAKA}

1. Ahyari, Agus, (2002), Manajemen Produksi (Perencanan Sistem Produksi), Edisi Keempat, Cetakan Ketiga, Penerbit BPFE, Yogyakarta.

2. Dharma, Agus, (2000), Manajemen Supervisi (PetunjukPraktis Bagi Supervisor), Edisi Pertama, Penerbit Raja Grafindo Persada, Jakarta.

3. Dharma, Agus, (2001), Manajemen Supervisi (PetunjukPraktis Bagi Supervisor), Edisi kedua, Penerbit Raja Grafindo Persada, Jakarta.

4. Dharma, Agus, (2002), Manajemen Prestasi Kerja, Cetakan Keempat, Penerbit Rajawali, Jakarta.

5. Dessler, Gary, (2002), Manajemen Personalia, Terjemahan : Agus Dharma, Edisi Keenam, Penerbit Arilangga, Jakarta.
6. Dessler, Gary, (2004), Manajemen Personalia, Terjemahan : Agus Dharma, Edisi Kedelapan, Penerbit Arilangga, Jakarta.

7. Flippo, Edwin B, (2002), Manajemen Personalia, Terjemahan : Moh. Mas'ud, EdisiKesembilan, Jilid 2, Cetakan Ke II, Penerbit Erlangga, Jakarta.

8. Gomes, Faustino, Cardoso, (2001), Manajemen Sumber Daya Manusia, Edisi Pertama, Cetakan Kelima, Penerbit ANDI Offset, Yogyakarta.

9. Gujarti, D, (2002), Ekonometrika Dasar, Alih Bahasa : Sumarno Zain, Penerbit Erlangga, Jakarta.

10. Handoko T. Hani, (2001), Manajemen Personalia dan Sumber Daya Manusia,edisi Kedua, Cetakan Keempat, Penerbit BPFE, Yogyakarta.

11. Handoko, T. Hani, (2002), Manajemen Personalia dan Sumberdaya Manusia, Edisi Kedua, Cetakan Kelima belas, Penerbit BPFE, Yogyakarta.

12. Hariandja, Marihot, Tua, Efendi, (2002), Manajemen Sumber Daya Manusia, Penerbit PT. Gramedia Widiasarana Indonesia, Jakarta.

13. Hasibuan, Malayu, (2001), Manajemen Sumber daya Manusia, Edisi Revisi, Cetakan Ketiga, Penerbit PT. Bumi Aksara, Jakarta.

14. Hasibuan, Malayu, (2005), Manajemen Sumber Daya Manusia, Edisi Revisi,Cetakan Kelima, Penerbit PT. Bumi Aksara, Jakarta.

15. Hasibuan, Malayu, (2006), Manajemen Sumber Daya Manusia, Edisi Revisi, Cetakan Keenam, Penerbit PT. Haji Masagung, Jakarta.

16. Kertonegoro, Sentonoe, (2001), Prinsip Jaminan Sosial dan Pelaksanaan di Indonesia, Cetakan Pertama, Penerbit Mutiara, Jakarta.

17. Kridalaksana, Hanmukti, (2000), Kamus Sinonim Bahan Indonesia, Edisi Ketujuh, Cetakan Ketiga, Penerbit Nusa Indah, Ende Flores.

18. M. Manullang, (2002), Manajemen Personalia, Jakarta : Ghalia Indonesia. Siagian, S. P. 2002. Manajemen Sumber Daya Manusia. Penerbit PT. Bumi Aksara Indonesia, Jakarta.

19. Mangkunegara, Prabu. Anwar, (2002), Manajemen Sumber Daya Manusia Perusahaan, Penerbit PT. Remaja Rosdakarya, Bandung.

20. Mangkunegara, Prabu. Anwar, (2004), Manajemen Sumber Daya Manusia Perusahaan, Penerbit PT. Remaja Rosdakarya, Bandung. 
21. Mangkunegara, Prabu. Anwar, (2005), Manajemen Sumber Daya Manusia Perusahaan, Penerbit PT. Remaja Rosdakarya, Bandung.

22. Mangkunegara, Prabu. Anwar, (2006), Manajemen Sumber Daya Manusia Perusahaan, Penerbit PT. Remaja Rosdakarya, Bandung.

23. Mangkunegara, Prabu. Anwar, (2007), Manajemen Sumber Daya Manusia Perusahaan, Penerbit PT. Remaja Rosdakarya, Bandung.

24. Mathis, Robert L dan Jackson, John H, (2001), Manajemen Sumber Daya Manusia, Penerbit PT. Salemba Empat, Jakarta.

25. Mathis, L. Robert dan Jackson, H. Jackson, (2002), Manajemen Sumber Daya Manusia, Buku 2, Penerbit Salemba Empat, Jakarta.

26. Nawawi, H. Hadari, (2003), Manajemen Sumber Daya Manusia, Untuk Bisnis Yang Kompetitif, Penerbit Gadjah Mada University Press, Yogyakarta.

27. Nawawi, H. Hadari, (2005), Manajemen Personalia, Cetakan Ketiga, Penerbit Gajah Mada Universitas Press, Yogyakarta.

28. Panggabean, Mutiara Sibarani, (2002), Manajemen Sumber Daya Manusia, Cetakan Pertama, Penerbit Ghalia Indonesia, Jakarta.

29. Ranupandojo, Heidrachman dan Husnan, Suad, (2001), Manajemen Personalia, Edisi Kelima, Cetakan Kelima, Penerbit BPFE, Yogyakarta.

30. Ravianto, J. (2000), Produktivitas Tenaga Kerja Indonesia, Cetakan Keempat, Penerbit UI Press, Jakarta.

31. Simamora, Henry, (2001), Manajemen Sumber Daya Manusia, edisi kedua, Penerbit Sekolah Tinggi Ilmu Ekonomi YKPN, Yogyakarta.

32. Simamora, Henry, (2004), Manajemen Sumber Daya Manusia, Edisi tiga, cetakan pertama, Penerbit Sekolah Tinggi Ilmu Ekonomi YKPN, Yogyakarta.

33. Sudjana, (2002), Teknik Analisis Regresi dan Korelasi Bagi Para Peneliti, Edisi Ketiga, Cetak Ulang Kedua Edisi Revisi, Penerbit TARSITO, Bandung.

34. Sugiono Dr. Prof, (2002), Metode Penelitian Bisnis, Cetakan Kesembilan, Penerbit CV Alfabeta, Bandung.

35. Sugiono Dr. Prof, (2003), Metode Penelitian Bisnis, Cetakan Kesembilan, Penerbit CV Alfabeta, Bandung.

36. Sugiono Dr. Prof, (2004), Metode Penelitian Bisnis, Cetakan Kesembilan, Penerbit CV Alfabeta, Bandung.

37. Sugiono Dr. Prof, (2006), Metode Penelitian Bisnis, Cetakan Kesembilan, Penerbit CV Alfabeta, Bandung.
38. Suharsimi, Arikunto, (2002), Prosedur Penelitian Suatu Pengantar, Penerbit Bina Aksara, Jakarta.

39. Syarif, Rusli, (2001), Teknik Manajeman Latihan dan Pengembangan, Edisi Revisi, Cetakan Ketiga, Penerbit Angkasa, Bandung.

40. Regina, Herzlinger and Jeffrey Schwartz, (2002), How Companies Tackle Health Care Costs, (Terjemahan) : Part I, Harvard Business Review 63 (July-August 2002).

41. Rivai, Vethzal, (2003), Manajemen Sumber Daya Manusia untuk Perusahaan, cetakan pertama, PT. Raja Grafindo Persada, Jakarta. Gramedia Pustaka Utama, Jakarta.

42. Rivai, Vethzal, (2004), Manajemen Sumber Daya Manusia untuk Perusahaan, cetakan pertama, PT. Raja Grafindo Persada, Jakarta. Gramedia Pustaka Utama, Jakarta.

43. Ruky, Achmad S., (2002), Sistem Manajemen Kinerja, Cetakan Ketiga, PT. Raja Grafindo Persada, Jakarta. Gramedia Pustaka Utama, Jakarta.

44. Michael, H Wiener, Walizer, L, Paul,(2000) Metode dan Analisis Penelitian Mencari Hubungan, Terjemahan : Arif Sukandi dan Sasid Hutangaol, Jilid Satu, Penerbit Arilangga, Jakarta 